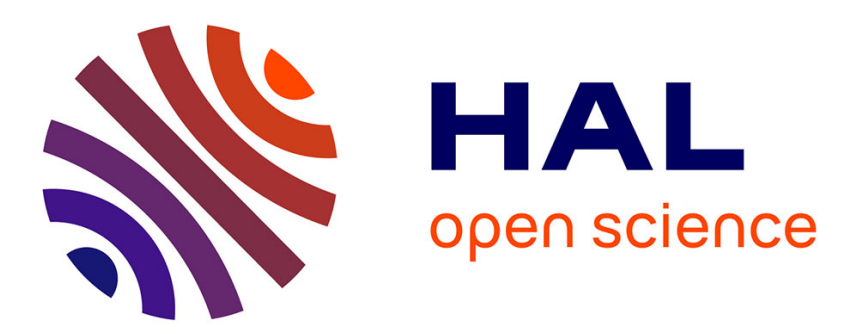

\title{
Do you envy others competitively or destructively?: an experimental and survey investigation
}

Gilles Grolleau, Naoufel Mzoughi, Angela Sutan, . Université Paris 5

\section{To cite this version:}

Gilles Grolleau, Naoufel Mzoughi, Angela Sutan,. Université Paris 5. Do you envy others competitively or destructively?: an experimental and survey investigation. SABE-IAREP International Congress in Behavioural Economics and Economic Psychology, Jul 2006, Paris, France. 20 p. hal02818370

\section{HAL Id: hal-02818370 \\ https://hal.inrae.fr/hal-02818370}

Submitted on 6 Jun 2020

HAL is a multi-disciplinary open access archive for the deposit and dissemination of scientific research documents, whether they are published or not. The documents may come from teaching and research institutions in France or abroad, or from public or private research centers.
L'archive ouverte pluridisciplinaire HAL, est destinée au dépôt et à la diffusion de documents scientifiques de niveau recherche, publiés ou non, émanant des établissements d'enseignement et de recherche français ou étrangers, des laboratoires publics ou privés. 
This version: July, 28, 2006

\title{
Do You Envy Others Competitively or Destructively? An Experimental and Survey Investigation
}

\author{
Gilles Grolleau \\ UMR INRA-ENESAD (CESAER) \\ BP 87999, 21079 Dijon Cedex France \\ Tel: + 33380772443 - Fax: + 33380772571 \\ grolleau@enesad.inra.fr \\ Naoufel Mzoughi \\ UMR INRA-ENESAD (CESAER) \\ BP 87999, 21079 Dijon Cedex France \\ Tel: + 33380772439 - Fax: + 33380772571 \\ mzoughi@enesad.inra.fr \\ Angela Sutan \\ Burgundy School of Business CEREN \\ 29, rue Sambin, 21000 Dijon France \\ Tél : +33 380725958 - Fax: +333807259 99 \\ asutan@escdijon.com
}

\begin{abstract}
Envy is evident when an agent undertakes a costly effort to reduce the gap between his situation and the envied others' situation. This attempt can take two paths. An agent characterized by competitive or white envy is willing to incur a cost in order to keep up with the Joneses' situation. An agent characterized by destructive or black envy is willing to incur a cost in order to push the others downwards. Using experiments and survey data, we show (1) that people exhibit competitive and destructive forms of envy and (2) that the dominant form of envy varies across domains. A major implication is that underdevelopment may be partly due to destructive envy.
\end{abstract}

Key words : behavioral economics; envy; subjective well-being.

JEL codes: D6, H0, J0. 


\title{
Do You Envy Others Competitively or Destructively? An Experimental and Survey Investigation
}

\author{
"In the misfortune of our best friends, we \\ always find something that is not displeasing \\ to us." (La Rochefoucauld, 1667)
}

\section{Introductory remarks}

The idea that interpersonal comparisons matter in agents' subjective well-being is so pervasive that the economics literature has recently devoted more attention to related issues such as positional goods and envy (e.g., Hirsch, 1976; Frank, 1985; Mui, 1995; Solnick and Hemenway, 1998, 2005). Envy occurs as soon as two individuals become capable of mutual comparison (Schoek, 1966, p.1). Envious behavior is so common - the fact that a person is unhappy if someone from his reference group has more than he has - that attempting to define it precisely may seem only quibbles over words. An envious person is likely to undertake efforts in order to reduce the gap between himself and the envied person. Reducing the gap may follow two distinct but non-mutually exclusive paths. First, the envious individual may invest in order to reach the position enjoyed by the envied individual. Second, the envious individual may invest in order to reduce the position of the envied individual, even by incurring a cost. While the final result may seem similar (gap reduction between the envious and envied people), the implications are significantly different. The first strategy, labeled competitive or white envy (closely related to the concept of ambition) boosts efforts in order to reach a higher position, e.g., the neighbor's income. Conversely, the second strategy called black or destructive envy destroys one's efforts to stand out from the crowd. In more mundane words, envy may generate a race to reach the envied person or a destructive investment to push him downwards. 
A growing economic literature supports that individuals care about their relative position and frequently envy someone else's position. A good introduction to the economics literature on envy may be found in Chaudhuri (1985), Hammond (1989), Mui (1995) and Kolm (1995). An individual $i$ is said to envy another individual $j$ if $i$ prefers $j$ 's allocation to his own. Noteworthy, we do not envy each individual in a given society, but "we envy those who are near us in time, place, age or reputation" (Aristotle, Rhetoric, 1338a). In other words, we do not envy Bill Gates' fortune but those who are closest to us in the considered domain, such as our neighbors, colleagues, friends or family members. Goel and Thakor (2005) provide a comprehensive literature review and distinguish envy literature from closely related approaches such as inequity-aversion (Fehr and Schmidt, 1999) and 'keeping up with the Joneses'. We do not replicate a similar review but rather focus on papers more directly related to our contribution.

We contend that envy may generate two kinds of behavior, i.e., competitive or white envy versus destructive or black envy. They are not mutually exclusive and frequently co-exist. They have been sparsely considered in the literature. One stream of literature emphasizes the destructive consequences of envy (Schoeck, 1966), when an envious person "prefers that others have less, and he might even sacrifice a little of his own wealth to achieve that end" (Zeckhauser 1991, p. 10). This face of envy is emphasized in the definition of envy given by Rawls (1971, p. 532) in the following terms: "we may think of [destructive] envy as the propensity to view with hostility the greater good of others even though their being more fortunate than we are does not detract from our advantages. We envy persons whose situation is superior to ours (estimated by some index of goods) ... and we are willing to deprive them of their greater benefits even if it is necessary to give up something ourselves ... The individual who envies another is prepared to do things that make them both worse off if only 
the discrepancy between them is sufficiently reduced." Such behavior has been supported by experimental evidence (Kirchsteiger 1994; Mui, 1995; Zizzo and Oswald, 2001). Supportive empirical evidence may also be found in the study of Lehman (2001). Individuals have to report satisfaction with the results of a sales competition between two stores in the same market for various combinations of sales. The individuals were more satisfied when the sales were equal but low for both the stores than when their own sales were higher but the sales of the competitor were even greater. An envious person increases his utility by destroying some of the others' assets, even if this is costly for him. For instance, Zizzo and Oswald (2001) show that people dislike other individuals' wealth sufficiently that they would be willing to pay some of their own money to reduce it. In Mui (1995), an innovator introduces an innovation and the envious follower may retaliate at a personal cost. The main result is that the threat of retaliation may deter innovation. Using experimental techniques in a multicountries setting, Beckman et al. (2002) show that opposition to Pareto gains may reach 60\% in some transitional countries, due to envy and malice.

A contrasting and less developed stream of literature argues that envious feelings may lead to invest more in order to achieve a status similar to the envied person. Envy that is a 'private vice' but a 'public virtue', might generate social benefits insofar at it encourages productive activities (Mandeville, 1714; Frank and Sunstein, 2001; McAdams, 1992). Marglin (2002, p. 23) describes envy as a 'virtue' that "serves an economic purpose in motivating individuals to maximum exertion and effort. The desire to improve one's relative status is the engine that drives the economic train (...). Envy [is] functional in promoting hard work, accumulation and economic growth." Indeed, the desire to get more, or at least the same amount of the envied thing, may motivate people adopting a productive behavior. This form of competitive envy has been considered as a powerful driver of the development of the American society 
(Matt, 2003) and as the "drive wheel of our modern world" (Palaver, 2004 and references therein). In this literature stream, a lack of envy or anti-envy devices (the so-called 'envy trap $^{1}$ ), either formal or informal, may prevent economic development (Tyler, 2004). In a similar vein, Fershtman et al. (2006) show that status concerns increase efforts and may lead to a 'rat race' among workers.

Envy is a good micro-motive candidate that may explain at least partially some macroeconomic variables such as development. Pareto (1968, p. 27) has recognized that "the greater part of human actions have their origin not in logical reasoning but in sentiment". In the following, we investigate empirically (1) whether positive and destructive envy matter in human decision making (2) and whether the dominant form of envy varies among domains. To address these issues, the remainder of the paper is organized as follows. The next section provides a conceptual framework to introduce the two dimensions of envious behaviors. Section 3 uses laboratory experiments and survey data to investigate competitive and destructive envy. Section 4 is devoted to policy implications and conclusive remarks.

\section{Conceptual framework and hypotheses}

Similarly to Hirschman and Rothschild (1973), we consider a society composed of two (or groups of) persons labeled $A$ and $B . B$ can be considered as a member of the so-called reference group. Assume that their utilities are interdependent in two distinct ways. A's utility depends on his own consumption level $C_{A}$, his expected consumption level $E_{A}$ and $B$ 's consumption level, $C_{B}$. Assume also that $A$ 's expectations $E_{A}$ partly depend on $B$ 's consumption.

$$
U_{A}(t)=V_{A}\left(C_{A}(t), E_{A}\left(C_{B}(t)\right), C_{B}(t)\right)
$$

\footnotetext{
${ }^{1}$ Kaplan, B., 2005, Escaping the Envy Trap, Econlog Issues and Insights in Economics, http://econlog.econlib.org/archives /2005/09/escaping_the_en.html
} 
It is obvious to assume that $A^{\prime}$ 's utility increases with his present and future consumption levels, that is, $\frac{\partial V_{A}(t)}{\partial C_{A}(t)} \geq 0$ and $\frac{\partial V_{A}(t)}{\partial E_{A}(t)} \geq 0$.

The effect of $B$ 's consumption on $A$ 's utility is more ambiguous. A evaluates it in two ways first, according to whether $B$ 's success (or failure) considered by itself pleases or displeases him and second, depending on what he thinks $B$ 's fate means for him. Thus,

$$
\frac{\partial U_{A}(t)}{\partial C_{B}(t)}=\frac{\partial V_{A}(t)}{\partial C_{B}(t)}+\frac{\partial V_{A}(t)}{\partial E_{A}(t)} \frac{\partial E_{A}(t)}{\partial C_{B}(t)}
$$

On the right side, the first term is the pure effect of $C_{B}$ on $V$, which is likely to be negative because $A$ is supposed to be driven by destructive envy. The second term $\frac{\partial V_{A}(t)}{\partial E_{A}(t)} \frac{\partial E_{A}(t)}{\partial C_{B}(t)}$ reflects $A$ 's concern for $B$ 's consumption as an indicator of his own future consumption level, which corresponds to competitive envy.

Empirically, the sign of $\frac{\partial U_{A}(t)}{\partial C_{B}(t)}$ may be interpreted as a test of the relative magnitude of these two effects. A negative sign indicates that destructive envy dominates competitive envy. A positive sign means that the competitive envy dominates the destructive envy. Hirschman and Rothschild (1973) coined the term 'tunnel effect'. In the authors' words, "the tunnel effect operates because advances of others supply information about a more benign external environment; receipt of this information produces gratification; and this gratification overcomes, or at least suspends, envy. Though long noted as the most uninviting of the seven 
deadly sins because, unlike lust, gluttony, pride, etc., it does not provide any initial fun to its practitioners, envy is nevertheless a powerful human emotion" (Hirschman and Rothschild, 1973, p. 546). In a similar way, a consumption gap, i.e., $B$ consumes more than $A$ can be interpreted in two different, but non-mutually exclusive ways and accordingly has two opposite effects on individual well-being. Destructive envy may generate the desire to decrease B's consumption because such a decrease will improve A's well-being while competitive envy may indicate to $A$ that $B$ 's increase may predict an increase in his future consumption.

Exhibiting no envy at all or destructive or competitive envy can lead to different behaviors, according to the extent of personal involvement in reducing the consumption gap. An agent can be either neutral to the consumption gap, or willing to reduce it, or even undertake an action to reduce it. Noteworthy, undertaking an action implies a willingness to reduce the gap whereas the same willingness may exist without resulting in observable actions. Observable actions to reduce the gap may be either competitive, when the envious individual attempts to reach the position enjoyed by the envied person or destructive, when the envious individual attempts to harm the position of the envied person. We contend that the discrepancy between the willingness to reduce the gap and the corresponding action is smaller when related to competitive envy than to destructive envy, due to the implied moral intensity.

Therefore, we explore 3 hypotheses related to the two dimensions of envy stressed above:

H1: Competitive and destructive envy matter in human decision making. In other words, people compare themselves to others in their reference group and are envious. 
Their relative position matters and they undertake actions to reduce the gap between them and the others, either competitively, either destructively or both.

H2: Envy is stronger for some goods than for others. Similarly to Solnick and Hemenway (1998, 2005 and references therein), we hypothesize that private goods are more envied than public goods.

H3: The magnitude of destructive and competitive envy varies among domains. We are not able to predict what domains are characterized by which dominant form of envy.

\section{Experiment and survey}

According to Posner $\left(2006^{2}\right)$, "studies of peasant societies find that "black" envy is widespread in them that is, if your neighbor has a nicer barn than yours, you'd prefer to burn it down than to exert yourself to build an equally good barn. "White" envy, in contrast, better described as emulation, promotes economic growth." To provide empirical information on envy feelings and behavior, we use two complementary empirical strategies, i.e., a decontextualized experiment and survey data.

\section{The experiment}

We designed a decontextualized experiment in which participants play in two member teams (player-opponent) and make choices about uncertain states of the world. They are paid according to the achievement of these states and their choices. In order to implement the required social neighborhood among participants, the subjects $(N=212)$ were recruited among

\footnotetext{
22 http://www.becker-posner-blog.com/archives/2006/04/
} 
students in an undergraduate course in the Burgundy School of Business. The experiment was paper-based and was conducted in November 2005.

There are two situations in the experiment (Table 1). Each situation is divided into two periods. In each period, a high and a low endowment are distributed between the player and his opponent. The roles are randomly attributed. The experimenter allocates the initial endowments and the distribution of the endowments in period 2 is chosen by the player. In the first situation, the endowment disparity is in favor of the player. Nevertheless, the opponent may also get a high endowment. In the second situation, the endowment disparity is in favor of the opponent. These situations are prevailing in the first period and the player has the possibility to choose the state of the world in period 2. A common knowledge risk is associated with the achievement of the future state of the world. The player has the possibility to accept the initial income distribution (neutral envy), to invest an amount of his initial endowment in order to see the opponent's endowment decreasing to the low level (black or destructive envy), or to invest an amount of his endowment in order to reach/bypass the high endowment himself (white or competitive envy). Following Kovacs et al. (2005), the high endowment is 10 euros, the low endowment is 3 euros, the cost of the competitive envy investment is 2 euros, and the cost of the destructive envy investment is 1 euro. If successful, the costly destructive effort may reduce the wealth of the opponent by 7 (the endowment gap) and the competitive effort may help the player to increase his wealth by 9 (the endowment gap plus the cost of the effort). The likelihood of reaching the expected competitive or destructive outcome is fixed at $20 \%$. The last two options in period 2 have a likelihood of achievement fixed at $80 \%$.

\section{[Insert Table 1]}


The main results drawn from the experiment are presented in table 2.

\section{[Insert Table 2]}

This decontextualized experiment shows that envy matters (Table 2), and, that participants exhibit more destructive than competitive envy (H1). The percentage of people exhibiting a destructive envy reaches $60 \%$. In the following, we contextualize the situations related to envy. Indeed, according to the experiment participants, playing for 3 or 10 euros is different from more real-life related situations.

\section{The survey}

The survey was administrated in April 2006 and June 2006 to a gender equilibrated sample of 208 participants. In order to ensure social proximity, the respondents were recruited among students attending courses at the University of Burgundy. We asked eight questions about public goods and private goods. The questions are hypothetical ${ }^{3}$ and relate to several items: degree, score, wage, pollution, roads, award, clothes, and work.

In the survey, the player and opponent correspond respectively to the respondent and reference group. Each question includes four states of the world. The initial state is such as the respondent has a worse situation than the others, i.e., $x_{i}{ }^{1}<x_{j}{ }^{1}$ ( $i$ stands for the respondent, $j$ for the reference group, 1 and 2 for the present and future situation). The respondent can

\footnotetext{
3 Several scholars (Thaler, 1987; Camerer and Hogarth, 1999) have expressed confidence in hypothetical surveys. They acknowledge that there is no significant difference between subjects who respond to hypothetical questions and those who receive some monetary incentives. Thaler (1987), who after reviewing a number of studies in which the difference between real and hypothetical payments did not yield important differences in results, notes that (p. 120) "asking purely hypothetical questions is inexpensive, fast, and convenient. This means that many more experiments can be run with much larger samples than is possible in a monetary-incentives methodology."
} 
either make a costly effort in order to reduce the gap between him and the others, or do nothing. When the agent makes the effort, the future situation can be such as $x_{j}{ }^{2}<x_{i}{ }^{2}<x_{i}{ }^{1}<$ $x_{j}{ }^{1}$ (destructive envy) or such as $x_{i}{ }^{2}=x_{j}{ }^{2}=x_{j}{ }^{1}>x_{i}{ }^{1}$ (competitive envy). When the agent does not make the effort, the future situation is $x_{i}{ }^{2}=x_{i}{ }^{1}<x_{j}{ }^{1}=x_{j}{ }^{2}$. This last situation can correspond to neutral envy (acceptation) or to a weaker form of envy in which the respondent can complain or give some fallacious arguments to devalue the others' position. One of the questions is given below ${ }^{4}$ :

Your actual wage is $€ 100000$ and your colleagues' wage is $€ 150000$ this year. What do you prefer for the next year?
A. Change nothing
B. I earn $€ 90000$ and my colleagues earn $€ 80000$
C. I make all possible efforts to earn $€ 130000$
D. I complain that their wage is unjustified, my performance being equivalent to theirs

The seven other questions of the survey are built on the same format. They relate to the following items: degree or diploma obtained (DEGREE), unsatisfactory score at exams (SCORE), pollution of residence area (POLLUTION), potholes in neighbourhood (ROADS), rank among managers of the same firm (AWARD), famous branded clothes (CLOTHES) and additional hours of work (WORK). Nevertheless, asking questions to the participants themselves $(\mathrm{N}=114)$ can induce their answers, especially if surveyed individuals do not want to give a bad image of themselves. Therefore, people are likely to underestimate destructive concerns and overestimate options perceived as more morally acceptable. To avoid such a bias, we conducted a second survey on similar participants $(\mathrm{N}=104)$ about others' reactions.

\footnotetext{
${ }^{4}$ The survey has been administrated in French. A full version of the questionnaires is available from authors upon request.
} 
In this case, the initial situation is such as $x_{i}{ }^{1}>x_{j}{ }^{1}$, with previous notations, and the respondent has to choose the situation that he thinks the others would choose. An example related to income is reported below:

Your actual wage is $€ 150000$ and your colleagues' wage is $€ 100000$ this year. What do you think your colleagues prefer for next year?
A. Change nothing
B. They earn $€ 90000$ and I earn $€ 80000$
C. They make all possible efforts to earn $€ 130000$
D. They complain that my wage is unjustified, their performance being equivalent to mine

Option A corresponds to neutral envy, option B corresponds to destructive envy related to an effort, option C corresponds to competitive envy, and option D corresponds to fallacious arguments aiming at devaluing the others' performance. We contend that the importance of destructive envy will be more accurately stated in the second formulation.

The main results from the surveys are reported in tables 3 and 4.

\section{[Insert Tables 2 and 3]}

R1: Again, the hypothesis H1 is confirmed. In the two surveys, people exhibit significant levels of envy, either competitive, either destructive. In the minimal situation, at least $15 \%$ of people exhibit a form or another of envy behavior. 
R2: The hypothesis $\mathrm{H} 2$ is also confirmed, that is, envy matters much more for some goods and attributes than it does for others (table 3). In the survey reporting oneself's behavior, the percentage of people exhibiting competitive envy reaches about $77 \%$ for the SCORE variable. The percentage of people exhibiting destructive envy reaches about $41 \%$ for the WORK variable. Except for CLOTHES, the variables corresponding to a private good (DEGREE, SCORE, WAGE, AWARD, WORK) generate a higher percentage of envious individuals than variables corresponding to public goods (POLLUTION, ROADS). The percentages related to the choice of the status quo situation are significant for most items.

When answering questions about others' behavior, the percentage of individuals choosing the destructive envy states is higher (table 4). From a methodological viewpoint, it seems that destructive envy is more easily stated when asking questions related to others' behavior rather than the individual's own behavior. This result could be useful for further studies using hypothetical questions by combining the two surveys, called thereafter the direct survey (on oneself's behavior) and the indirect survey (on others' behavior as perceived by the surveyed individual).

R3: The hypothesis $\mathrm{H} 3$ is also confirmed. Indeed, the magnitude of each form of envy varies among domains. Destructive envy is the highest for the situation related to work (WORK), either for oneself (41\%) or for others $(66 \%)$. Competitive envy is the highest for the situations related to the score (SCORE) in the direct survey (77\%) and to the award (AWARD) in the indirect survey $(66 \%)$. Our results corroborate the assumption that the magnitude of each kind of envy varies among domains, but it is premature to draw any regularity from our data. Investigating the relative magnitude of each kind of envy among domains constitutes a 
challenging and promising issue that may explain why similar policy approaches implemented in different domains but for the same people may lead to different outcomes.

\section{Conclusive remarks}

Envy is a pervasive feeling that can be found in every society. Envy may be either destructive or competitive or a combination of these two dimensions. The dominant dimension varies among domains. According to the dominant dimens ion, the behavior of individuals and their consequences differ significantly. Starting from this basic tenet, incorporating systematically envy into economic analysis can provide a refreshing way to consider conventional issues, such as transition and development or at a lower level, e.g., human relationships in organizations.

We contend that the literature on transition and innovation-based development has not devoted sufficient attention to the role of moral and psychological factors. Envy is intuitively a good candidate for micromotives that generate macro-effects. Indeed, competitive or emulative envy may be considered as the motor of economic development and growth while destructive envy may prevent such a competition needed to growth. According to the prevailing feeling in a given society, policymakers willing to promote growth cannot use a 'one size fits all' policy. In societies dominated by competitive envy, helping leaders to emerge may emulate others to join them. Inversely, in societies dominated by destructive envy, egalitarian policies are likely to be more effective than policies oriented towards leaders. Such effects may at least partially explain why policies of developing countries failed to promote a similar development path in developed countries characterized by a different dominant envy. An important and intriguing issue relates to the process(es) or path(es) by which destructive envy may be transformed into competitive envy. 
Moreover, in societies dominated by competitive envy, successful people are more likely to publicize their success and fear less being envied by others. Conversely, in destructive envy societies, people may be more likely to hide their success to not be envied by others, except if they feel themselves sufficiently protected against destructive strategies of the others from the reference group. Such effects may explain why incentives may be public information while individual results remain secret to prevent destructive strategy by reference group members (Bebchuk and Fried, 2003; Charness and Kuhn, 2004). Indeed, such destructive strategies and the subsequent protective devices are negative sum game.

A natural extension to our contribution is to test whether envy varies in magnitude and types among countries. Interestingly, a popular story depicting American versus Russian behavior seems to acknowledge such differences as follows: "One American farmer has a neighbor that just got a prize cow. A Russian farmer similarly has a neighbor with a prize cow. The American farmer's dream: to have a better cow than the neighbor. The Russian farmer's dream: that the neighbor's cow dies" $\left(\mathrm{Grey}^{5}, 2001\right)$. We expect that our contribution will open a door to generate among economists the desire (maybe the envy) to go further on these cheeky and challenging issues.

\section{References}

Bebchuk, LA.; Fried, JM., 2003, Executive compensation as an agency problem, Journal of Economic perspectives, 17(3): 71-92.

Beckman, S. Formby, J., Smith, J., and Zheng, B., 2002, Envy, Malice and Pareto efficiency: An experimental examination, Social Choice and Welfare, 19: 349-367.

\footnotetext{
${ }^{5}$ http://www.mail-archive.com/armchair@gmu.edu/msg01520.html.
} 
Camerer, C.; Hogarth, R., 1999, The effects of Financial Incentives In Experiments: A review and Capital-Labor Production Framework, Journal of Risk and Uncertainty, 19, 7-42.

Charness G; Kuhn, P., 2005, Pay Inequality, Pay Secrecy, and Effort: Theory and Evidence, NBER Working Paper.

Chaudhuri, A., 1985, Formal Properties of Interpersonal Envy, Theory and Decision, 18(3): 301-312.

Elster, J., 1991, Envy in Social Life in R. Zeckhauser (ed.), Strategy and Choice, The MIT Press, Ch. 3: 49-82.

Fehr, E.; Schmidt, KM., 1999, A Theory of Fairness, Competition and Cooperation, Quarterly Journal of Economics, 114: 817-868.

Fershtman, C., H. Vide and Weiss, Y. 2006, "Cultural Diversity, Status Concerns and the Organization of Work," Research in Labor Economics, 24:361-396.

Frank, R.; Sunstein, C., 2001, Cost-Benefit Analysis and Relative Position," with Cass Sunstein, The University of Chicago Law Review, 68(2): 323-374.

Frank, R.H., 1985, The Demand for Unobservable and Other Nonpositional Goods', American Economic Review, 75(1): 101-116.

Goel, AM and Thakor, AV., 2005, Green with Envy: Implications for Corporate Investment Distortions, Journal of Business, 78(6): 2255-2287.

Hammond, P., 1989, Envy, The New Palgrave Dictionary of Economics, London: Macmillan: 45-48.

Hirsch, F. (1976), Social Limits to Growth, Cambridge. Harvard University Press.

Hirschman, AO.; Rothschild, M., 1973, The Changing Tolerance for Income Inequality in the Course of Economic Development, The Quarterly Journal of Economics, 87(4): 544-566. 
Kirchsteiger, G., 1995, The Role of Envy in Ultimatum Games, Journal of Economic Behaviour and Organization, 25: 373-389.

Kolm, SC., 1995, The Economics of Social Sentiments: The Case of Envy, The Japanese Economic Review, 46(1): 63-87.

Kovacs, T, Csukas, C., Sutan, A. 2005 My neighbour's greener grass and my dead goat: an experiment on positive and negative envy, IMEBE, Valencia, déc. 2005.

Lehmann, DR., 2001, The Impact of Altruism and envy on competitive behaviour and satisfaction, International Journal of Research in Marketing, 18: 5-17.

Mandeville, B., 1714, The Fable of the Bees; or, Private Vices, Public Benefits.

Matt, SJ., 2003, Keeping Up with the Joneses: Envy in American Consumer Society, 18901930. Philadelphia: University of Pennsylvania Press, 2003.

Marglin, SA., 2002, Economic Myths, Séminaire Hétérodoxies, MATISSE, University of Paris I (http://matisse.univ-paris1.fr/doc2/EcoMyths.pdf).

McAdams, R. H. (1992). Relative Preferences, The Yale Law Journal. 102: 1-104.

Mui, V., 1995. The economics of envy. Journal of Economic Behavior and Organization 26, $311-336$.

Palaver, W., 2004, Envy or Emulation: A Christian Understanding of Economic Passions, Mimeo.

Rawls, J., 1971, A Theory of Justice, Cambridge, Massachusetts, Harvard University Press.

Solnick, S.; Hemenway, D., 1998. Is more always better? A survey on positional concerns. Journal of Economic Behavior and Organization 37, 373-383. 
Solnick, S.; Hemenway, D., 2005. Are positional Concerns Stronger in Some domains than in Others? American Economic Review Papers and Proceedings Vol 95, N² 2, May 2005, 147 151.

Thaler, R. (1987): "The psychology of choice and the assumptions of economics," in Laboratory experimentation in economics: Six points of view, ed. by Roth, A., pp. 99-130. Cambridge University Press, Cambridge.

Tyler, C., 2004, Markets and Cultural Voices, The University of Michigan Press, Ann Arbor. Zeckhauser, R., 1991, Strategy and Choice, Cambridge, Massachusetts: MIT Press.

Zizzo, DJ.; Oswald, A., 2001, Are People Willing to Pay to Reduce Others' Incomes? Annales d'Economie et de Statistiques, 63-64: 39-66. 
Table 1: The experimental design

\section{Situation 1}

\begin{tabular}{llc}
\hline Initial allocation & \multicolumn{1}{c}{ Form of envy } & Outcome \\
\hline & $\begin{array}{l}\text { Neutral envy: the player does not prevent the opponent from } \\
\text { getting 7 more euros }\end{array}$ & $(10,10)$ \\
\cline { 2 - 2 } & $\begin{array}{l}\text { Competitive envy: the player makes a costly effort }(-2) \text { to } \\
\text { reach the level enjoyed by the opponent }\end{array}$ & $\begin{array}{c}(10-2+9,10)=(17,10) \\
\text { with 20\% risk }\end{array}$ \\
\cline { 2 - 2 }$(10,3)$ & & $\begin{array}{c}(10-2,10)=(8,10) \\
\text { with } 80 \% \text { risk }\end{array}$ \\
\cline { 2 - 3 } & $\begin{array}{l}\text { Destructive envy: the player undertakes a costly effort }(-1) \text { to } \\
\text { destroy the opponent's chance to get } 7 \text { euros }\end{array}$ & $\begin{array}{c}(10-1,3)=(9,3) \\
\text { with } 20 \% \text { risk }\end{array}$ \\
& & $\begin{array}{c}(10-1,10)=(9,10) \\
\text { with } 80 \% \text { risk }\end{array}$ \\
\hline
\end{tabular}

\section{Situation 2}

\begin{tabular}{llc}
\hline Initial allocation & \multicolumn{1}{c}{ Form of envy } & Outcome \\
\hline & $\begin{array}{l}\text { Neutral envy: the player does not change the initial } \\
\text { allocation }\end{array}$ & $(3,10)$ \\
\cline { 2 - 3 } & $\begin{array}{l}\text { Competitive envy: the player makes a costly effort }(-2) \text { to } \\
\text { reach the level enjoyed by the opponent }\end{array}$ & $\begin{array}{c}(3-2+9,10)=(10,10) \\
\text { with } 20 \% \text { risk }\end{array}$ \\
\cline { 2 - 2 }$(3,10)$ & $\begin{array}{l}(3-2,10)=(1,10) \\
\text { with } 80 \% \text { risk }\end{array}$ \\
\cline { 2 - 3 } & $\begin{array}{l}\text { Destructive envy: the player undertakes a costly effort }(-1) \text { to } \\
\text { destroy the opponent's wealth }\end{array}$ & $\begin{array}{c}(3-1,10-7)=(2,3) \\
\text { with } 20 \% \text { risk }\end{array}$ \\
& & $\begin{array}{c}(3-1,10)=(2,10) \\
\text { with } 80 \% \text { risk }\end{array}$ \\
\hline
\end{tabular}


Table 2: Main results from the experiment

\begin{tabular}{|c|c|c|c|}
\hline & $\begin{array}{c}\begin{array}{c}\text { Destructive } \\
\text { envy }\end{array} \\
\end{array}$ & Status quo & $\begin{array}{c}\text { Competitive } \\
\text { envy }\end{array}$ \\
\hline $\begin{array}{l}\text { The endowment disparity is in the favor of the } \\
\text { opponent. }\end{array}$ & $60 \%$ & $11 \%$ & $29 \%$ \\
\hline $\begin{array}{l}\text { The endowment disparity is in the favor of the player. } \\
\text { But, the opponent can get the high endowment too. }\end{array}$ & $50 \%$ & $18 \%$ & $32 \%$ \\
\hline
\end{tabular}

Table 3: Results from the survey on individuals

\begin{tabular}{|c|c|c|c|c|c|c|c|c|}
\cline { 2 - 9 } \multicolumn{1}{c|}{} & DEGREE & SCORE & WAGE & POLLUTION & ROADS & AWARD & CLOTHES & WORK \\
\hline Competitive envy & $22,32 \%$ & $76,99 \%$ & $65,79 \%$ & $51,33 \%$ & $13,39 \%$ & $56,25 \%$ & $0,88 \%$ & $44,64 \%$ \\
\hline $\begin{array}{c}\text { Destructive envy } \\
\text { (effort) }\end{array}$ & $19,64 \%$ & $1,77 \%$ & $9,65 \%$ & $5,31 \%$ & $18,75 \%$ & $2,68 \%$ & $12,39 \%$ & $41,07 \%$ \\
\hline $\begin{array}{c}\text { Destructive envy } \\
\text { (willingness) }\end{array}$ & $2,68 \%$ & $1,77 \%$ & $2,63 \%$ & $1,77 \%$ & $2,68 \%$ & $1,79 \%$ & $1,77 \%$ & $2,68 \%$ \\
\hline Status quo & $55,36 \%$ & $19,47 \%$ & $21,93 \%$ & $41,59 \%$ & $65,18 \%$ & $39,29 \%$ & $84,96 \%$ & $11,61 \%$ \\
\hline
\end{tabular}

Table 4: Results from the survey on others

\begin{tabular}{|c|c|c|c|c|c|c|c|c|}
\cline { 2 - 9 } \multicolumn{1}{c|}{} & DEGREE & SCORE & WAGE & POLLUTION & ROADS & AWARD & CLOTHES & WORK \\
\hline Competitive envy & $12,74 \%$ & $58,82 \%$ & $42,57 \%$ & $58,41 \%$ & $26,47 \%$ & $69,00 \%$ & $12,87 \%$ & $18,81 \%$ \\
\hline $\begin{array}{c}\text { Destructive envy } \\
\text { (effort) }\end{array}$ & $29,41 \%$ & $14,70 \%$ & $40,59 \%$ & $18,81 \%$ & $43,13 \%$ & $10,00 \%$ & $37,62 \%$ & $66,33 \%$ \\
\hline $\begin{array}{c}\text { Destructive envy } \\
\text { (willingness) }\end{array}$ & $11,76 \%$ & $0,98 \%$ & $3,96 \%$ & $3,96 \%$ & $2,94 \%$ & $7,00 \%$ & $2,97 \%$ & $4,95 \%$ \\
\hline Status quo & $46,07 \%$ & $25,49 \%$ & $12,87 \%$ & $18,81 \%$ & $27,45 \%$ & $14,00 \%$ & $46,53 \%$ & $9,90 \%$ \\
\hline
\end{tabular}

